\title{
Expression Patterns of Growth Related Genes in Juvenile Red Spotted Grouper (Epinephelus akaara) with Different Growth Performance after Size Grading
}

\author{
Seong Hee Mun ${ }^{1}$, Jin Ho You ${ }^{1}$, Hyeon Ji Oh${ }^{1}$, Chi Hoon Lee ${ }^{2}$, \\ Hea Ja Baek ${ }^{3}$,Young-Don Lee ${ }^{4}$, and ${ }^{\dagger}$ Joon Yeong Kwon' ${ }^{1}$ \\ ${ }^{I}$ Dept. of Aquatic Life Medical Science, Sunmoon University, Asan 31460, Korea \\ ${ }^{2}$ CR Co., Ltd., Jeju 63333, Korea \\ ${ }^{3}$ Dept. of Marine Biology, Pukyong National University, Busan 48513, Korea \\ ${ }^{4}$ Dept. of Marine Science Institute, Jeju National University, Jeju 63333, Korea
}

\begin{abstract}
Fish shows great difference in growth rate between individuals during larval development and early growth. This difference seriously reduces the production efficiency in fish culture. Growth hormone (GH)/Insulin-like growth factor 1 (IGF1) system is said to play some pivotal roles in fish growth. In this study, we investigated differences of GH, IGF1 and GHR gene expressions in juvenile red spotted grouper (Epinephelus akaara) with different growth performance. Red spotted groupers were reared under the same environmental condition (water temperature $24 \pm 1^{\circ} \mathrm{C}$, natural light) for 96 days after hatching. They were divided into 3 groups by size (fast growing, middle growing and slow growing groups: FGG, MGG, and SGG, respectively). RNA was extracted from the brain, liver and muscle tissues from each group, and target gene expression was examined by real-time PCR. In the brain with pituitary gland, expression of GH gene in FGG was significantly higher than the expression in SGG, but the expression of IGF1 and GHR genes in the muscle was highest in SGG. Difference of GHR and IGF1 mRNA in the liver between groups with different growth performance was less clear than that in other tissues, although level of IGF1 mRNA was higher in SGG than in MGG. These results suggest that hormonal governing of growth is not the same in fast growing and slow growing fish, and size grading could cause a shift of hormonal state and growth pattern in this species.
\end{abstract}

Key words : Red spotted grouper, Growth hormone, Insulin-like growth factor 1, Growth hormone receptor, Size grading

\section{INTRODUCTION}

Aquaculture practice for red spotted grouper Epinephelus akaara, a popular choice for culture in the region of south east Asia, is being shifted from 'capture-based culture' to 'full-cycle culture' which utilizes 'seed' produced in hatcheries (Rimmer \& Glamuzina, 2019). One of the frequently faced problems in the process of the full-cycle culture for this species is severe size variation at early life stage. This size difference between individuals at early stage could seriously reduce the production efficiency of larvae (Barki et al., 2000).

In general, a wide size distribution is known to be disadvantageous in aquaculture due to social growth suppres-

\footnotetext{
Manuscript received January 14, 2019, Received in revised form February 22, 2019, Accepted March 9, 2019

${ }^{\dagger}$ Corresponding Author: Joon Yeong Kwon, Dept. of Aquatic Life Medical Sciences, Sunmoon University, Asan 31460, Korea. Tel: +82-41-530-2284, Fax: +82-41-530-2917, E-mail: jykwon@sunmoon.ac.kr
}

This is an Open Access article distributed under the terms of the Creative Commons Attribution Non-Commercial License (http:// creative-commons.org/licenses/by-nc/3.0) which permits unrestricted non-commercial use, distribution, and reproduction in any medium, provided the original work is properly cited. 
sion of small individuals (Ruzzante, 1994), resulting fast growing and slow glowing fish within a population. Despite of the disadvantage, biological differences between fast growing and slow glowing fish at the level of endocrinology are not known. Improved understanding on the endocrinological differences between fast growing and slow glowing fish should identify the cause of size variation and suggest better solutions, although size grading partly relieves the problem of wide size distribution.

Growth hormone (GH)/insulin-like growth factor 1 (IGF1) system is associated with body growth and nutrient metabolism in mammals and teleost (Peter \& Marchant, 1995; Moriyama et al., 2000). GH, a peptide hormone produced by the pituitary gland, binds to the growth hormone receptor (GHR) in target tissues (Perez-Sanchez et al., 2002; Reinecke et al., 2005). GH mRNA is expressed in the brain and gonad as well as the pituitary in fish (Biga et al., 2004; $\mathrm{Li}$ et al., 2005). GH also produces IGF1 by stimulating the liver and other tissues (Pierce et al., 2004). Many of the actions of GH are mediated by IGF1 (Kopchick \& Andry, 2000). Supportingly, GHR expression is the highest in the liver, though it is expressed in tissues other than the liver (reviewed by Canosa et al., 2007). Likewise, IGF1 mRNA expression has also been demonstrated in both hepatic and nonhepatic tissues of adult fish, including salmonids (Sakamoto \& Hirano, 1993), tilapia Oreochromis mossambicus (Reinecke et al., 1997) and goldfish Carassius auratus (Otteson et al., 2002). IGF1 is a key regulatory hormone that stimulates somatic growth, affecting different tissues (Kumar et al., 2013). IGF1 is involved in various physiological processes such as growth of cartilage and bone tissue and muscle tissue, cell proliferation, myoblast differentiation, embryonic development, hormone production, and oocyte maturation (Coolican et al., 1997; Wood et al., 2005; Ohlsson et al., 2009). Thus, the GH/IGF1 system is an important regulatory network that plays a major role in the endocrine control of fish growth.

It is natural to expect that this growth-governing endo- crinology system would not be the same in fast growing and slow growing fish. In this study, we divided juvenile red spotted grouper into three groups (fast growing, middle growing and slowing growing groups) by size grading and compared the expression of GH, GHR, and IGF1 genes in relevant tissues (brain, liver and muscle) to find out endocrinological differences between fish with different growth performance.

\section{MATERIALS AND METHODS}

\section{Experimental fish and sampling}

Juvenile red spotted grouper used in this study were grown for 96 days after hatching in Marine Science Institute of Jeju National University (Jeju, Korea) before size grading. During this period, fish were reared in round tanks $(3.5 \mathrm{~m}$ in diameter) with continuous supply of seawater (salinity 34 psu, water temperature $24 \pm 1^{\circ} \mathrm{C}$ ) under natural photoperiod. They were fed every two hours with artificial feed.

Fish were graded by their size and accommodated separately into three different tanks. Accordingly, the fish in each tank was assigned as fast growing group (FGG), middle growing group (MGG), slow growing group (SGG). Twenty fish from each group were randomly sampled within a week after the size grading and killed by overdose of an anesthetic substance (Benzocaine, Sigma Aldrich) to measure body length $(\mathrm{BL}, \mathrm{cm})$, body height $(\mathrm{BH}, \mathrm{cm})$ and body weight (BW, g) (Table 1). The brain including the pituitary, liver and muscle tissues from each fish after the measurement were removed and stored at $-80^{\circ} \mathrm{C}$ for further analysis.

\section{Preparation of RNA and real-time PCR}

Total RNA was extracted using Trizol ${ }^{\circledR}$ reagent (ambion, USA) from the tissues of each fish from FGG, MGG, and SGG according to the manufacturer's protocol. cDNA was synthesized using TOPscript ${ }^{\mathrm{TM}} \mathrm{RT}$ DryMIX (Enzynomics, Korea). To investigate GH, GHR, and IGF1 genes for red 
Table 1. Information of fish used to investigate differential expression of GH, GHR, and IGF1 genes

\begin{tabular}{cccc}
\hline \hline Group & BL $(\mathrm{cm})$ & BH $(\mathrm{cm})$ & BW $(\mathrm{g})$ \\
\hline Fast growing group (FGG) & $7.2 \pm 0.6$ & $2.2 \pm 0.2$ & $6.3 \pm 1.5$ \\
Middle growing group (MGG) & $6.1 \pm 0.4$ & $1.8 \pm 0.2$ & $3.6 \pm 0.6$ \\
Slow growing group (SGG) & $5.1 \pm 0.5$ & $1.5 \pm 0.2$ & $2.2 \pm 0.6$ \\
\hline
\end{tabular}

GH, growth hormone; GHR, growth hormone receptor; IGF1, insulin-like growth factor 1; BL, body length; BH, body height; BW, body weight.

spotted grouper, real-time PCR was carried out with CFX96 Touch $^{\mathrm{TM}}$ Real-Time PCR Detection System (Bio-Rad, USA) using the ToprealTM ${ }^{T P C R} 2 X$ PreMIX SYBR Green (Enzynomics, Korea). The PCR reaction was performed with an initial denaturation at $95^{\circ} \mathrm{C}$ for $15 \mathrm{~min}$, followed by 40 cycles of ' $72^{\circ} \mathrm{C}$ for $30 \mathrm{~s}, 65^{\circ} \mathrm{C}$ for $15 \mathrm{~s}$, and $72^{\circ} \mathrm{C}$ for $30 \mathrm{~s}^{\prime}$ in $20 \mu \mathrm{L}$ of reaction. $\beta$-actin gene was included as a reference gene. All reactions were run in duplicate. Negative control without cDNA was included in each assay.

Primers for the target genes (GH, GHR, and IGF1 genes together with $\beta$-actin gene) were designed based on the sequences available online (database provided by National Center for Biotechnology information: www.ncbi.nlm.gov). Primers for $\mathrm{GH}$ and $\beta$-actin gene were species-specific because their sequences are available for red spotted grouper. However, primers for GHR and IGF1 gene were degenerate based on the sequences of orange spotted grouper Epinephelus coioides and longtooth grouper Epinephelus bruneus, respectively, due to the absence of previous study on the genes in red spotted grouper (Table 2). The sizes of PCR products matched well to the expected size of each primer set.

\section{Statistical analysis}

All data for gene expression were expressed as mean values \pm S.E.M. Statistical differences between FGG, MGG, and SGG were evaluated by using one-way ANOVA followed by Duncan's multiple range test. A probability level

Table 2. Primers used for quantitative real-time PCR (qRT-PCR)

\begin{tabular}{ccccc}
\hline \hline Gene & & Sequences & $\begin{array}{c}\text { Product size } \\
(\mathrm{bp})\end{array}$ & $\begin{array}{c}\text { Accession } \\
\text { number }\end{array}$ \\
\hline$\beta$-actin & $\mathrm{F}$ & ATCACACCTTCTACAACGAGC & 122 & HQ007251 \\
$\beta$-actin & $\mathrm{R}$ & GAAGGTCTCGAACATGATCTGG & \multirow{2}{*}{ AY326406 } \\
\hline GH & $\mathrm{F}$ & GACTGTTCTCCATCGCTGTC & \multirow{2}{*}{ EF052273 } \\
GH & $\mathrm{R}$ & CAGACTGCTCTCAAAGTCGG & 133 & \\
\hline GHR & $\mathrm{F}$ & TCAAACCATACACCCTCAGC & AB902571 \\
GHR & $\mathrm{R}$ & CTGTACCACTGTGTAGTCTGC & 123 & \\
\hline IGF1 & $\mathrm{F}$ & ATGTAGGGAAGGTGCGAATG & & \\
IGF1 & $\mathrm{R}$ & CCTTTGTCAGCATCCTCTTTG &
\end{tabular}

GH, growth hormone; GHR, growth hormone receptor; IGF1, insulin-like growth factor 1. 
of less than 0.05 was used to indicate significance. All analyses were performed using the SPSS 18.0 software.

\section{RESULTS}

Expression of GH mRNA in the brain+pituitary tissue of juvenile red spotted grouper was examined by means of real-time PCR (Fig. 1). GH mRNA was expressed in the

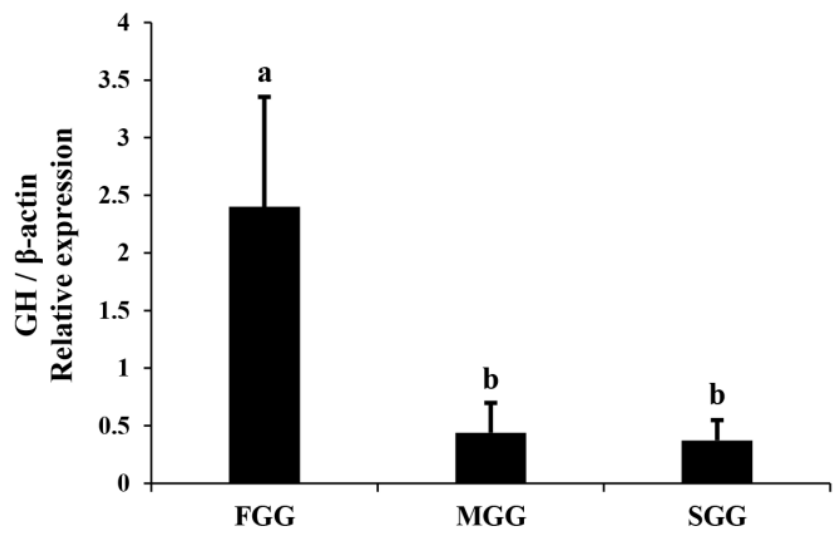

Fig. 1. Expression level of GH mRNA in the brain+pituitary of juvenile red spotted grouper with different growth performance. Data represent the mean \pm SEM ( $n=14-20)$. Different letters above the bars represent significant differences $(p<0.05)$. FGG, fast growing group; MGG, middle growing group; $\mathrm{SGG}$, slow growing group; $\mathrm{GH}$, growth hormone.

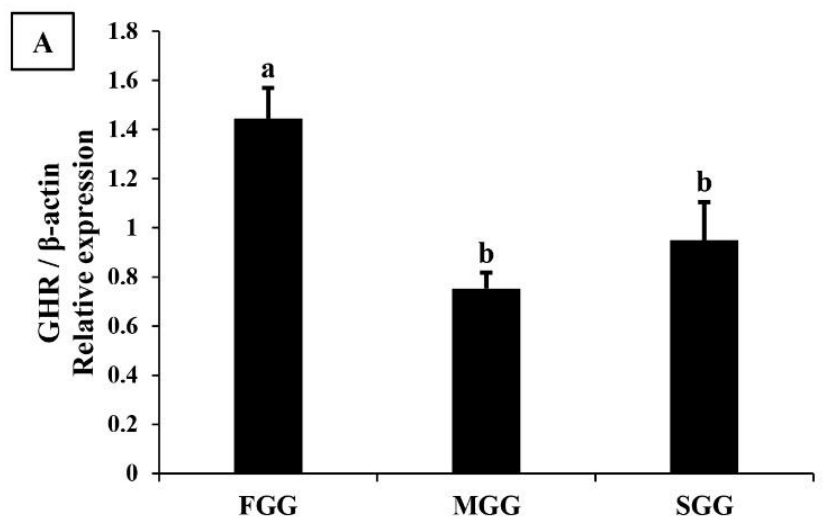

brain+pituitary tissue but not in the liver or muscle tissue of this species. Expression of GH gene in FGG was more than 5-fold higher than in MGG and SGG $(p<0.05)$.

In the liver, expression level of GHR mRNA was slightly higher in FGG than in MGG and SGG $(p<0.05)$, while IGF1 mRNA was highest in the SGG (Fig. 2). However, the differences between groups in the liver were not as dramatic as in the brain. Expression levels of GHR and IGF1 mRNA in the muscle of SGG were 2-3 fold higher than the levels in FGG and MGG ( $p<0.05$; Fig. 3).

\section{DISCUSSION}

It seems that fast growing and slow growing fish are different to each other at the level of endocrinology. Furthermore, expression patterns of growth related genes such as GH, GHR, and IGF1 genes are tissue-specifically altered in response to size grading in red spotted grouper.

GH/IGF1 system rules fish growth in which the actions of GH are mediated by IGF1 (Kopchick \& Andry, 2000). IGF1 is a key regulatory hormone that stimulates somatic growth, affecting different tissues (Kumar et al., 2013). Ideal growth performance is thought to be achieved with low plasma GH (i.e., low GH mRNA in the pituitary) in

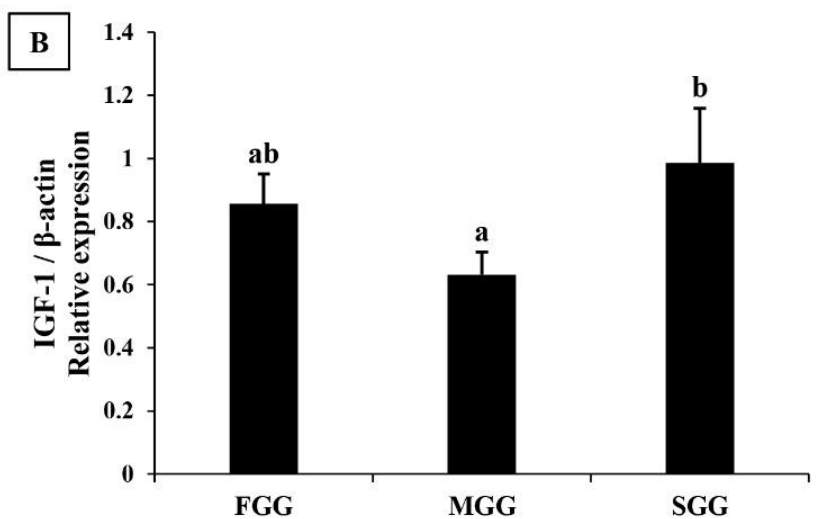

Fig. 2. Expression levels of GHR (A), IGF1 (B) mRNA in the liver of juvenile red spotted grouper with different growth performance. Data represent the mean \pm SEM $(n=19-20)$. Different letters above the bars represent significant differences $(p<0.05)$. FGG, fast growing group; MGG, middle growing group; SGG, slow growing group; GHR, growth hormone receptor; IGF1, insulin-like growth factor 1. 

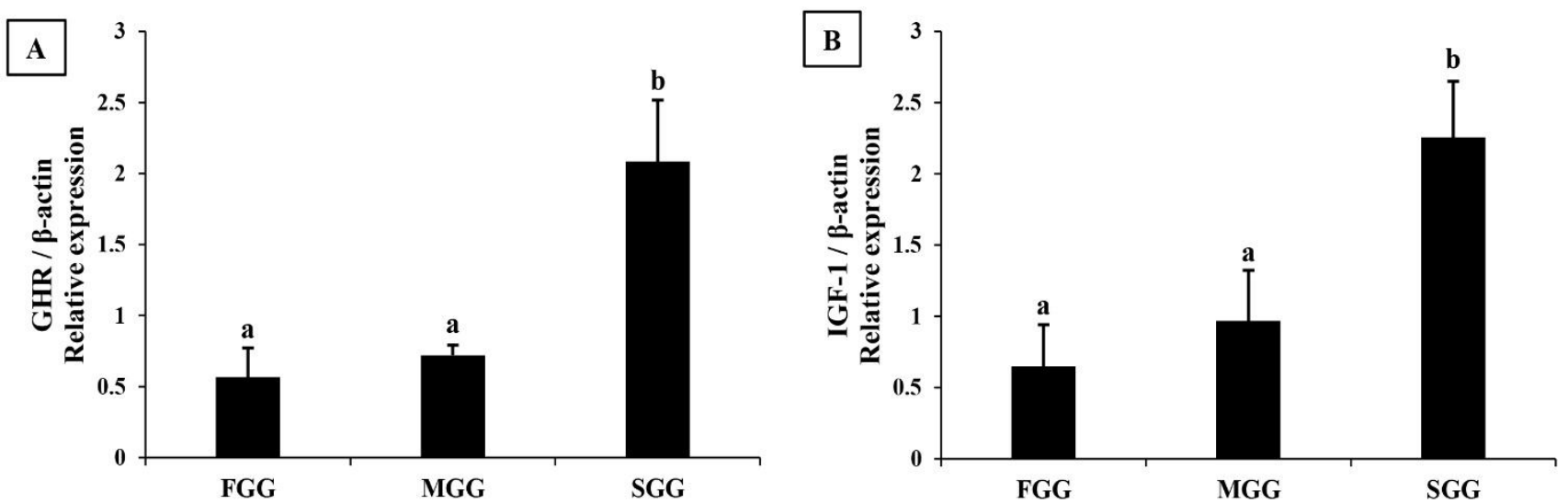

Fig. 3. Expression levels of GHR (A), IGF1 (B) mRNA in the muscle of juvenile red spotted grouper with different growth performance. Data represent the mean \pm SEM $(n=19-20)$. Different letters above the bars represent significant differences $(p<0.05)$. FGG, fast growing group; MGG, middle growing group; SGG, slow growing group; GHR, growth hormone receptor; IGF1, Insulin-like growth factor 1.

combination with a high concentration of hepatic GHRs and high circulating levels of IGFs (meaning high IGF mRNA in the liver) (Perez-Sanchez \& Le Bail, 1999). This was supported by a series of experiments where exogenous IGF1 suppressed GH secretion in white perch Morone americana indicating negative feedback (Fruchtman et al., 2000). Our results, however, do not conform to this ideal model.

Contradictory to the conventional view, in the present study, the level of GH mRNA in the brain (with pituitary) was most abundant not in SGG but in FGG. Instead, the levels of IGF1 mRNA in the liver and muscle were highest in SGG. There seems some ambiguity in the previous studies regarding the relationship between GH/IGF1 and growth performance in fish. Exogenous treatment of $\mathrm{GH}$ have been shown to be growth promoting in a series of studies (Johnsson et al., 1999). In crucian carp C. auratus, fast growing fish (triploids) showed significantly more expression of pituitary GH mRNA, hepatic GHR and IGF1 mRNA and muscle IGF1 mRNA than slow growing fish (diploids) (Zhong et al., 2012). In the larvae of European sea bass Dicentrarchus labrax, expression level of IGF1 mRNA in fast growing fish was significantly higher than the level in slowing growing fish (Carnevali et al., 2006). However, no difference of IGF1 mRNA in the liver and muscle between fast and slow growing families of channel catfish Ictalurus punctatus have been found (Peterson et al., 2004; 2008). In rainbow trout Oncorhynchus mykiss, expression of IGF1 mRNA was different depending on tissues (high in the liver but no change in the muscle) in FGG (Gabillard et al., 2003). No changes of GH and IGH1 mRNA have also been noticed in zebrafish Danio rerio larvae with different growth performance (Opazo et al., 2017).

Factors influencing on GH/IGF1 system is highly intricate, which include many endocrine and environmental factors relevant to the diverse physiological circumstances where GH is involved. In this system, a low level of GH in the pituitary may indicate a high secretion rate or a low level of GH synthesis, and a high plasma level may reflect high synthesis or low turnover by GHRs (Tymchuk et al., 2009).

One obvious factor that makes GH/IGF1 system complicate is nutritional status of fish. Growth retarded fish by unsuitable diet showed several fold decrease of growth related genes including hepatic GHR, IGF1 and IGF2 genes in red spotted grouper (Yang et al., 2018). Food deprivation have also been shown to be associated with elevated plasma GH in rainbow trout (Norbeck et al., 2007), and 
elevated plasma GH and pituitary GH mRNA level in fasted fish of seawater-acclimated tilapia O. mossambicus, whereas significant reductions were observed in plasma IGF-I and hepatic IGF-I mRNA levels in these fish (Fox et al., 2006). Refeeding after fasting dramatically increased IGF mRNA particularly in the muscle within 4 days in rainbow trout implying a change to compensatory growth mode (Chauvigne et al., 2003). Effect of size grading on smaller fish could be comparable to the effect of refeeding after fasting.

In the present study, fish with different growth performance were all mixed together in the same tanks until the size grading, indicating slow growing fish in the tank had been under severe stress due to the competition for food and space. Under this circumstance, small fish must undoubtedly have had less chances to access food, and their growth might have been suppressed. By size grading, however, the smaller fish would have been relieved from the stress and started to produce growth promoting factors including IGF1. On the other hand, larger fish having dominated in the mixed group has now faced much more competition for food and space. This explanation suggest a shift of hormonal state and growth pattern has taken place in fish by size grading, meaning shift of SGG to compensatory mode and shift of FGG to stressed state. This fits well to the results (higher IGF1 mRNA in the liver and muscle of SGG after size grading) obtained in this study. In support of this, stressors (e.g., osmotic shock, handling, and confinement) that elicited an increase in serum cortisol, have been shown to result in concomitant declines in serum IGF-1 concentrations in Atlantic salmon Salmo salar, southern bluefin tuna Thunnus maccoyii, silver perch Bidyanus bidyanus, and black bream Acanthopagrus butcheri (Dyer et al., 2004). Intraperitoneal injections of cortisol have also been proved to suppress both plasma IGF-1 and hepatic IGF-1 mRNA expression in tilapia O. mossambicus (Kajimura et al., 2003).

High level of GH mRNA observed in the brain tissue containing pituitary of FGG in this study appears to be pituitary origin rather than hypothalamic origin since no GH mRNA were detected in the brain alone when the pituitary produced high level of GH mRNA in a very closely related species, orange spotted grouper (Li et al., 2005). High level of GH mRNA in the pituitary accompanied by high level of IGF1 mRNA in the liver and muscle also supports the idea of hormonal state and growth pattern shift.

Results from this study suggest that growth-governing endocrinology is not the same in fast growing and slow growing fish, and size grading could cause a shift of hormonal state and growth pattern in this species. Further studies on the difference of GH/IGF1 system before and after size grading could provide useful information to resolve this complicate hormonal growth-governing in this species.

\section{ACKNOWLEDGMENTS}

This research was supported by the Korean Ministry of Agriculture, Food and Rural Affairs (MAFRA), the Korean Ministry of Oceans and Fisheries (MOF), the Korean Rural Development Administration (RDA), and Korea Forest Service (KFS) (Grant number: 213008-05-3-WT511).

\section{REFERENCES}

Barki A, Harpaz S, Hulata G, Karplus I (2000) Effects of larger fish and size grading on growth and size variation in fingerling silver perch. Aquac Int 8:391-401.

Biga PR, Schelling GT, Hardy RW, Cain KD, Overturf K, Ott TL (2004) The effects of recombinant bovine somatotropin (rbST) on tissue IGF-I, IGF-I receptor, and GH mRNA levels in rainbow trout, Oncorhynchus mykiss. Gen Comp Endocrinol 135:324-333.

Canosa LF, Chang JP, Peter RE (2007) Neuroendocrine control of growth hormone in fish. Gen Comp Endocrinol 151:1-26.

Carnevali O, Vivo LD, Sulpizio R, Gioacchini G, Olivotto 
I, Silvi S, Cresci A (2006) Growth improvement by probiotic in European sea bass juveniles (Dicentrarchus labrax, L.), with particular attention to IGF-1, myostatin and cortisol gene expression. Aquaculture 258:430-438.

Chauvigne F, Gabillard JC, Weil C, Rescan PY (2003) Effect of refeeding on IGFI, IGFII, IGF receptors, FGF2, FGF6, and myostatin mRNA expression in rainbow trout myotomal muscle. Gen Comp Endocrinol 132:209215.

Coolican SA, Samuel DS, Ewton DZ, McWade FJ, Florini JR (1997) The mitogenic and myogenic actions of insulin-like growth factors utilize distinct signaling pathways. J Biol Chem 272:6653-6662.

Dyer AR, Upton Z, Stone D, Thomas PM, Soole KL, Higgs N, Quinn K, Carragher JF (2004) Development and validation of a radioimmunoassay for fish insulinlike growth factor I (IGF-I) and the effect of aquaculture related stressors on circulating IGF-I levels. Gen Comp Endocrinol 135:268-275.

Fox BK, Riley LG, Hirano T, Grau EG (2006) Effects of fasting on growth hormone, growth hormone receptor, and insulin-like growth factor-I axis in seawater-acclimated tilapia, Oreochromis mossambicus. Gen Comp Endocrinol 148:340-347.

Fruchtman S, Jackson L, Borski R (2000) Insulin-like growth factor I disparately regulates prolactin and growth hormone synthesis and secretion: Studies using the teleost pituitary model. Endocrinology 141:2886-2894.

Gabillard JC, Weil C, Rescan PY, Navarro I, Gutierrez J, Bail PYL (2003) Effects of environmental temperature on IGF1, IGF2, and IGF type I receptor expression in rainbow trout (Oncorhynchus mykiss). Gen Comp Endocrinol 133:233-242.

Johnsson JI, Petersson E, Jonsson E, Jarvi T, Bjornsson BTH (1999) Growth hormone-induced effects on mortality, energy status and growth: A field study on brown trout (Salmo trutta). Funct Ecol 13:514-522.
Kajimura S, Hirano T, Visitacion N, Moriyama S, Aida K, Grau EG (2003) Dual mode of cortisol action on GH/ IGF-I/IGF binding proteins in the tilapia, Oreochromis mossambicus. J Endocrinol 178:91-99.

Kopchick JJ, Andry JM (2000) Growth hormone (GH), GH receptor, and signal transduction. Mol Genet Metab $71: 293-314$

Kumar V, Khalil WKB, Weiler U, Becker K (2013) Influences of incorporating detoxified Jatropha curcas kernel meal in common carp (Cyprinus carpio L.) diet on the expression of growth hormone- and insulin-like growth factor-1-encoding genes. J Anim Physiol Anim Nutr 97:97-108.

Li WS, Chen D, Wong AOL, Lin HR (2005) Molecular cloning, tissue distribution, and ontogeny of mRNA expression of growth hormone in orange-spotted grouper (Epinephelus coioides). Gen Comp Endocrinol 144:7879.

Moriyama S, Ayson FG, Kawauchi H (2000) Growth regulation by Insulin-like growth factor-I in fish. Biosci Biotechnol Biochem 64:1553-1562.

Norbeck LA, Kittilson JD, Sheridan MA (2007) Resolving the growth-promoting and metabolic effects of growth hormone: Differential regulation of GH-IGF-I system components. Gen Comp Endocrinol 151:332-341.

Ohlsson C, Mohan S, Sjogren K, Tivesten A, Isgaard J, Isaksson O, Jansson JO, Svensson J (2009) The role of liver-derived insulin-like growth factor-I. Endocr Rev 30:494-535.

Opazo R, Valladares L, Romero J (2017) Comparison of gene expression patterns of key growth genes between different rate growths in zebrafish (Danio rerio) siblings. Lat Am J Aquat Res 45:766-775.

Otteson DC, Cirenza PF, Hitchcock PF (2002) Persistent neurogenesis in the teleost retina: Evidence for regulation by the growth-hormone/insulin-like growth factorI axis. Mech Dev 117:137-149.

Peter RE, Marchant TA (1995) The endocrinology of growth 
in carp and related species. Aquaculture 129:299-321.

Peterson BC, Waldbieser GC, Bilodeau L (2004) IGF-I and

IGF-II mRNA expression in slow and fast growing families of USDA103 channel catfish (Ictalurus punctatus). Comp Biochem Physiol A Mol Integr Physiol 139:317-323.

Peterson BC, Small BC, Waldbieser GC, Bosworth BG (2008) Endocrine responses of fast- and slow-growing families of channel catfish. N Am J Aquac 70:240-250.

Perez-Sanchez J, Le bail PY (1999) Growth hormone axis as marker of nutritional status and growth performance in fish. Aquaculture 177:117-128.

Perez-Sanchez J, Calduch-Giner JA, Mingarro M, VegaRubin de Celis S, Gomez-Requeni P, Saera-Vila A, Astola A, Valdivia MM (2002) Overview of fish growth hormone family. New insights in genomic organization and heterogeneity of growth hormone receptors. Fish Physiol Biochem 27:243-258.

Pierce AL, Dickey JT, Larsen DA, Fukada H, Swanson P, Dickgoff WW (2004) A quantitative real-time RT-PCR assay for salmon IGF-I mRNA, and its application in the study of GH regulation of IGF-I gene expression in primary culture of salmon hepatocytes. Gen Comp Endocrinol 135:401-411.

Reinecke M, Schmid A, Ermatinger R, Loffing-Cueni D (1997) Insulin-like growth factor I in the teleost Oreochromis mossambicus, the tilapia: Gene sequence, tissue expression, and cellular localization. Endocrinology 138:3613-3619.
Reinecke M, Bjornsson BT, Dickhoff WW, McCormick SD, Navarro I, Power DM, Gutierrez J (2005) Growth hormone and insulin-like growth factors in fish: Where we are and where to go. Gen Comp Endocrinol 142:2024.

Rimmer MA, Glamuzina B (2019) A review of grouper (Family Serranidae: Subfamily Epinephelinae) aquaculture from a sustainability science perspective. Rev Aquac 11:58-87.

Ruzzante DE (1994) Domestication effects on aggressive and schooling behavior in fish. Aquaculture 120:1-24.

Sakamoto T, Hirano T (1993) Expression of insulin-like growth factor I gene in osmoregulatory organs during seawater adaptation of the salmonid fish: Possible mode of osmoregulatory action of growth hormone. Proc Natl Acad Sci USA 90:1912-1916.

Tymchuk WE, Beckmen B, Devlin RH (2009) Altered expression of growth hormone/insulin-like growth factor I axis hormones in domesticated fish. Endocrinology 150:1809-1816.

Wood AW, Duan C, Bern HA (2005) Insulin-like growth factor signaling in fish. Int Rev Cytol 243:215-285.

Yang Y, Han T, Xiao J, Li X, Wang J (2018) Transcriptome analysis reveals carbohydrate-mediated liver immune responses in Epinephelus akaara. Sci Rep 8:639.

Zhong H, Zhou Y, Liu S, Tao S, Long Y, Liu Z, Zhang C, Duan W, Hu J, Song C, Liu Y (2012) Elevated expressions of GH/IGF axis genes in triploid crucian carp. Gen Comp Endocrinol 178:291-300. 